Supplement of Clim. Past, 15, 1757-1769, 2019

https://doi.org/10.5194/cp-15-1757-2019-supplement

(C) Author(s) 2019. This work is distributed under

the Creative Commons Attribution 4.0 License.

(c) (1)

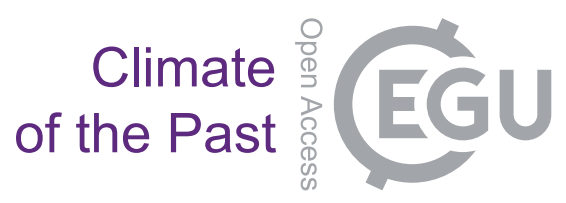

Supplement of

\title{
Enhanced Mediterranean water cycle explains increased humidity during MIS 3 in North Africa
}

Mike Rogerson et al.

Correspondence to: Mike Rogerson (m.rogerson@hull.ac.uk)

The copyright of individual parts of the supplement might differ from the CC BY 4.0 License. 


\section{Supplemental Information 1:}

\section{Searching for signs of early alteration and other "diagenetic" influences in speleothem SC-06-01}

Our finding that the fluid inclusion isotopes do not lie on a single meteoric water line is consistent with the presence of two competing behaviours in precipitation isotopes of the region (Gat et al., 2003), but it could also arise from early alteration of the calcite after enclosure of the inclusions. We therefore consider it responsible to evaluate whether there is any evidence for alteration within the sample, especially evidence of cements growing within speleothem cavities.

The speleothem comprises almost entirely of primary columnar calcite, with frequent zones of microcrystalline calcite oriented perpendicular to growth (Fig. S1). The columnar fabric is highly typical of speleothem growth in equilibrium with dripwater, whereas the micrite layers occur at hiatuses and are indicative of a degree of bio-influence (Frisia, 2015;Frisia et al., 2000;Dupraz et al., 2009). Micrite layers in SC-06-01 are an original fabric (Frisia, 2015). We find no evidence of either microsparite or mosaic fabrics within this specimen, and therefore no evidence of alteration or transformation of an early carbonate phase.

Fluid inclusions themselves are unequally distributed, being far richer in milky layers typical of rapid growth phases than the rather glassy layers typical of slower growth (growth rate here in inferred from the distance between adjacent U-Th datings (Hoffmann et al., 2016). They are generally elongate, with their long axes oriented with the long axes of calcite columns. Larger inclusions universally show uneven margins, and no inclusion has been identified showing evidence of transformation towards a low aspect ratio, near-spherical form (Meckler et al., 2015). The larger inclusions generally have cuspate terminations, typical of inclusions formed during speleothem growth (Meckler et al., 2015). Smaller inclusions are also generally elongate, although some low aspect ratio inclusions can be found. Nevertheless, these resemble primary inclusions, with either cuspate or thorn-like closure in the growth direction.

Demény et al (2016) provide a vital framework for identification of alteration of fluid inclusions. Their work indicates that this process will be more common in cooler regions, making it relatively unlikely for an African specimen. Reconstructions of LGM winter-time (the likely season of maximum speleothem growth, and therefore fluid inclusion closure) sea surface temperatures for the Cyrenaican coast indicate a change from modern conditions $<2^{\circ} \mathrm{C}$ (Hayes et al., 2005). This implies that cave temperature was likely no lower than $\sim 18^{\circ} \mathrm{C}$ during MIS3.

Although Demény et al (2016) describe a process occurring in very young speleothems, they provide no upper age limit for Ostwald ripening to drive isotopic change in fluid inclusions. Looking for the signal of this process in SC-06-01, we find that the isotope measurements themselves do not systematically change with distance from speleothem top (age), but rather show a constant mean behaviour, with a slight bias to more negative values in Phase II rather than Phase I (Fig. 4). The 
correspondence of the absolute magnitude of the measurements to modern rainfall isotopes for the region also requires that, for alteration sensu Demény (2016) to have taken place, these must perfectly compensate for some independent alteration of the system in the opposite direction. Moreover, although the broad distribution of the measurements in $\delta^{18} \mathrm{O}_{\mathrm{fi}}$ could arise from depletion during alteration (Demény et al., 2016), isotopically negative $\delta^{18} \mathrm{O}_{\mathrm{fi}}$ correspond to enriched $\delta^{2} \mathrm{H}_{\mathrm{fi}}$, causing a weak negative correlation between these values rather than a simple translation in oxygen isotopes. This is unlike the trend described by Demény et al (2016), but is consistent with the difference between Tunis-mode and Bet Dagan-mode rainfall today.

Another potential way of identifying diagenetic alteration is looking for non-equilibrium fractionation between the fluid inclusions and the hosting calcite. Due to the complexity of estimating what compositions are where two populations of inclusions are present, we perform this analysis for the subset of data where fluid inclusion isotope measurements are fully replicated (Fig. 6). Modern mean winter temperature in Dernah (the nearest city to Susah Cave) is $11.9^{\circ} \mathrm{C}$, with maximum $17.7^{\circ} \mathrm{C}$ and minimum $7.1^{\circ} \mathrm{C}$. Estimated palaeo-temperatures of equilibrium are shown in Table S1. We conclude that these fluid inclusions are therefore certainly at least close to isotopic equilibrium with the carbonate hosting them.

Table S1. Analysis of likely equilibrium fractionation of fully duplicated sub-set of fluid inclusion measurements.

\begin{tabular}{|c|c|c|c|c|c|c|c|}
\hline $\begin{array}{c}\text { Duplicated } \\
\text { Sample }\end{array}$ & $\begin{array}{c}\text { Mean } \\
\delta^{18} \mathrm{O}_{\mathrm{fi}}\end{array}$ & $\begin{array}{c}\text { Mean } \\
\delta^{2} \mathrm{H}_{\mathrm{fi}}\end{array}$ & $\begin{array}{c}\text { Distance From } \\
\text { Base }(\mathrm{mm})\end{array}$ & Age & $\delta^{18} \mathrm{O}_{\mathrm{cc}}$ & $\begin{array}{c}\text { Temperature } \\
\left({ }^{\circ} \mathrm{C}\right)^{1}\end{array}$ & $\begin{array}{c}\text { Growth } \\
\text { Phase }\end{array}$ \\
\hline 9 & -4.35 & -21.51 & $15-20$ & $66394-66388$ & -3.78 & 13.3 & $\mathrm{I}$ \\
\hline 11 & -5.69 & -19.95 & $56-61$ & $66493-64393$ & -3.96 & 8.7 & $\mathrm{I}$ \\
\hline 18 & -5.92 & -21.75 & $109-118$ & $63487-63302$ & -3.98 & 7.9 & I \\
\hline 23 & -5.45 & -25.62 & $260-267$ & $59106-58490$ & -4.51 & 11.8 & I \\
\hline 25 & -5.38 & -25.54 & $395-400$ & $51687-51648$ & -5.21 & 15.0 & II \\
\hline 33 & -4.70 & -26.72 & $556-561$ & $37260-37221$ & -4.37 & 14.3 & III \\
\hline 29 & -5.08 & -22.72 & $597-602$ & $36957-36921$ & -4.6 & 13.7 & III \\
\hline 35 & -5.03 & -21.37 & $652-657$ & $36581-36284$ & -3.82 & 10.8 & III \\
\hline 7 & -4.96 & -23.74 & $767-772$ & $35688-35647$ & -4.32 & 13.1 & III \\
\hline
\end{tabular}

${ }^{1}$ Calculated using the equation presented by (Sharp, 2017).

Overall, we therefore find no evidence in favour of alteration or "diagenetic" influence on the SC-0601 fluid inclusion dataset. In absence of any such data, we feel on good grounds to interpret these data as palaeo-environmentally useful.

\section{References}

\footnotetext{
${ }^{1}$ Calculated using the equation presented by Sharp, Z.: Principles of stable isotope geochemistry, 2017.
} 
Demény, A., Czuppon, G., Kern, Z., Leél-Őssy, S., Németh, A., Szabó, M., Tóth, M., Wu, C.-C., Shen, C.C., and Molnár, M.: Recrystallization-induced oxygen isotope changes in inclusion-hosted water of speleothems-Paleoclimatological implications, Quaternary International, 415, 25-32, 2016.

Dupraz, C., Reid, R. P., Braissant, O., Decho, A. W., Norman, R. S., and Visscher, P. T.: Processes of carbonate precipitation in modern microbial mats, Earth-Science Reviews, 96, 141-162, http://dx.doi.org/10.1016/i.earscirev.2008.10.005, 2009.

Frisia, S., Borsato, A., Fairchild, I. J., and McDermott, F.: Calcite Fabrics, Growth Mechanisms, and Environments of Formation in Speleothems from the Italian Alps and Southwestern Ireland, Journal of Sedimentary Research, 70, 1183-1196, 10.1306/022900701183, 2000.

Frisia, S.: Microstratigraphic logging of calcite fabrics in speleothems as tool for palaeoclimate studies., International Journal of Speleology, 44, 1-16. , 2015.

Gat, J. R., Klein, B., Kushnir, Y., Roether, W., Wernli, H., Yam, R., and Shemesh, A.: Isotope composition of air moisture over the Mediterranean Sea: An index of the air-sea interaction pattern, Tellus, Series B: Chemical and Physical Meteorology, 55, 953-965, 10.1034/j.1600-

0889.2003.00081.x, 2003.

Hayes, A., Kucera, M., Kallel, N., Sbaffi, L., and Rohling, E. J.: Glacial Mediterranean sea surface temperatures based on planktonic foraminiferal assemblages, Quaternary Science Reviews, 24, 9991016, 2005.

Hoffmann, D. L., Rogerson, M., Spötl, C., Luetscher, M., Vance, D., Osborne, A. H., Fello, N. M., and Moseley, G. E.: Timing and causes of North African wet phases during MIS 3 and implications for Modern Human migration, Nature Scienfiic Reports, 6, 36367, 2016.

Meckler, A. N., Affolter, S., Dublyansky, Y. V., Krüger, Y., Vogel, N., Bernasconi, S. M., Frenz, M., Kipfer, R., Leuenberger, M., and Spötl, C.: Glacial-interglacial temperature change in the tropical West Pacific: a comparison of stalagmite-based paleo-thermometers, Quaternary Science Reviews, 127, 90-116, 2015.

Sharp, Z.: Principles of stable isotope geochemistry, 2017. 